Proceedings

\title{
Preparation and characterization of thiosemicarbazone ligands and study of their iron and palladium derivatives ${ }^{\dagger}$
}

\author{
Paula Munín ${ }^{1, *}$, Fátima Lucio-Martínez ${ }^{1}$, Francisco Reigosa ${ }^{1}$, Adolfo Fernandez-Figueiras ${ }^{1}$, José \\ M. Vila ${ }^{1}$, M. Teresa Pereira ${ }^{1}$, Juan M. Ortigueira ${ }^{1}$ \\ 1 Departamento de Química Inorgánica, Facultad de Química, Universidad de Santiago de Compostela, Avd. \\ das Ciencias s/n, 15782 Santiago de Compostela, Spain; paula.munin@usc.es; mariadefatima.lucio@usc.es; \\ francisco.reigosa@usc.es; adolfo.fernndez@usc.es; josemanuel.vila@usc.es; mteresa.pereira@usc.es; \\ juanm.ortigueira@usc.es \\ * paula.munin@usc.com; Tel.: +34-881-814-442 \\ + Presented at the 21st International Electronic Conference on Synthetic Organic Chemistry, 1-30 November \\ 2017.
}

Academic Editor: name

Received: date; Accepted: date; Published: date

\begin{abstract}
Transition metal complexes are useful in organic synthesis due to the capability of the metal to activate substrates [1-2]; in particular, cyclometallation reactions may lead to novel routes in organic synthesis. Thiosemicarbazones show a high coordinative capacity given that they possess several potential donor atoms through which they can bind to transition metals. In addition, thiosemicarbazones as well as their semicarbazones analogues have considerable biological and pharmacological interest [3] because of their antibacterial, antiviral and antitumor activity. Their derivatives with ferrocenyl phosphines such as 1,1'bis(diphenylphosphine)ferrocene (dppf) show a wide range of applications [4].
\end{abstract}

Keywords: Thiosemicarbazones; palladium; iron; dppf

\section{Introduction}

Palladium cyclometallated compounds have cytotoxic properties [5-6] similar to platinum antitumor drugs; in addition,it is well known that palladium also shows has catalytic properties in cross-coupling reactions [7-8]. Tertiary phosphines are commonly used as ligands in coordination chemistry [9]. In the present work, we present a family of palladium cyclometallated compounds derived from thiosemicarbazone ligands containing the diphosphine 1,1'-bis(diphenylphosphine)ferrocene, dppf, which shows interesting catalytical, photochemical, photophysical and electrochemical properties [10-13].

\section{Materials and Methods}

\subsection{Synthesis of the ligands}

Thiosemicarbazones are obtained by condensation reaction between the aldehyde or ketone carbonyl group and the amino group of a thiosemicarbazide. The synthesis of the thiosemicarbazone 
ligands was carried out in aqueous medium because the reaction product precipitates as a white solid. For this process acidification is necessary to activate the carbonyl group.<smiles>COc1ccc(C(C)=O)cc1O</smiles>

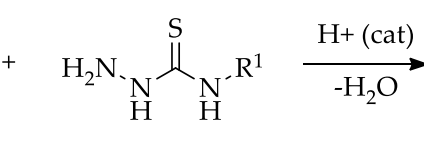

$\mathrm{R}^{1}=\mathrm{H}, \mathrm{Me}, \mathrm{Et}, \mathrm{Ph}$<smiles>COc1ccc(/C(C)=N/NC(=S)NO)cc1OC</smiles>

$\mathrm{R}^{1}=\mathrm{H}, \mathrm{Me}, \mathrm{Et}, \mathrm{Ph}$

$1 a, 2 a, 3 a, 4 a$

Scheme 1. Synthesis of the thiosemicarbazone ligands.

\subsection{Synthesis of the cyclometallated compounds}

Cyclometallated compounds are those contain a $\sigma \mathrm{M}-\mathrm{C}$ bond and also a covalent coordinated bond with a donor atom. Palladium and platinum cyclometallated compounds with thiosemicarbazone ligands have been described, these compounds have a very characteristic tetranuclear structure (Figure 1), containing two types of Metal-S bonds: Metal-Schelate and Metal-Sbridging. The metal atom, is bonded to the carbon in the ortho position and coordinated to a nitrogen atom and two different sulfur atoms.

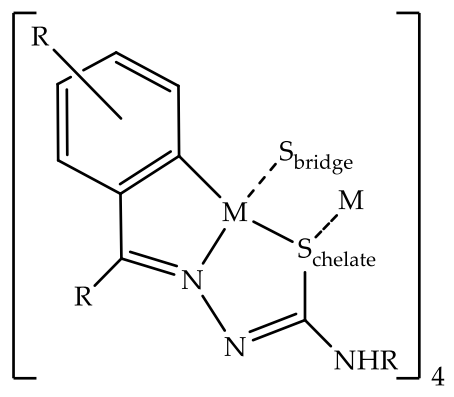

(a)

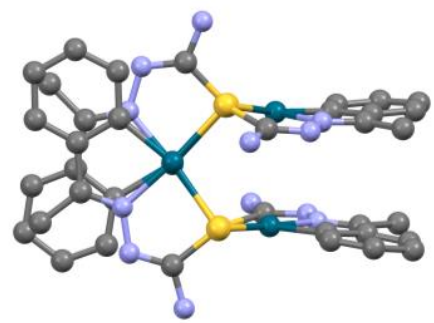

(b)

Figure 1. (a) Representation of a tetrameric structure. (b) X-Ray resolution of a tetrameric structure.

Potassium tetrachloropalladate was used as metallating agent and a water-ethanol mixture as a solvent. The products precipitate within the solution and due to their tetrameric structure they are rather insoluble so they are usually characterized by proton NMR using DMSO-d 6 as solvent.<smiles>[R1]NC(=S)N/N=C(\C)c1ccc(OC)c(OC)c1</smiles>

$\mathrm{R}^{1}=\mathrm{H}, \mathrm{Me}, \mathrm{Et}, \mathrm{Ph}$

$1 a, 2 a, 3 a, 4 a$

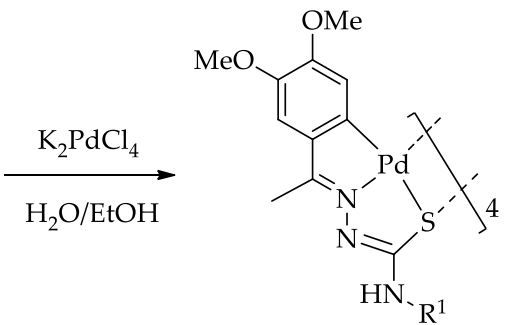

$\mathrm{R}^{1}=\mathrm{H}, \mathrm{Me}, \mathrm{Et}, \mathrm{Ph}$

$1 b, 2 b, 3 b, 4 b$

Scheme 2. Synthesis of the cyclometallated compounds. 


\subsection{Synthesis of the compounds bearing phosphine}

The synthesis of the cyclometallated compounds with phosphine ligands was carried out using acetone as solvent at room temperature. It is remarkable that although four equivalents of diphosphine were added, all the products obtained showed the diphosphine acts in a bridging mode. These products precipitate giving a pure product and leaving the diphosphine excess in solution.

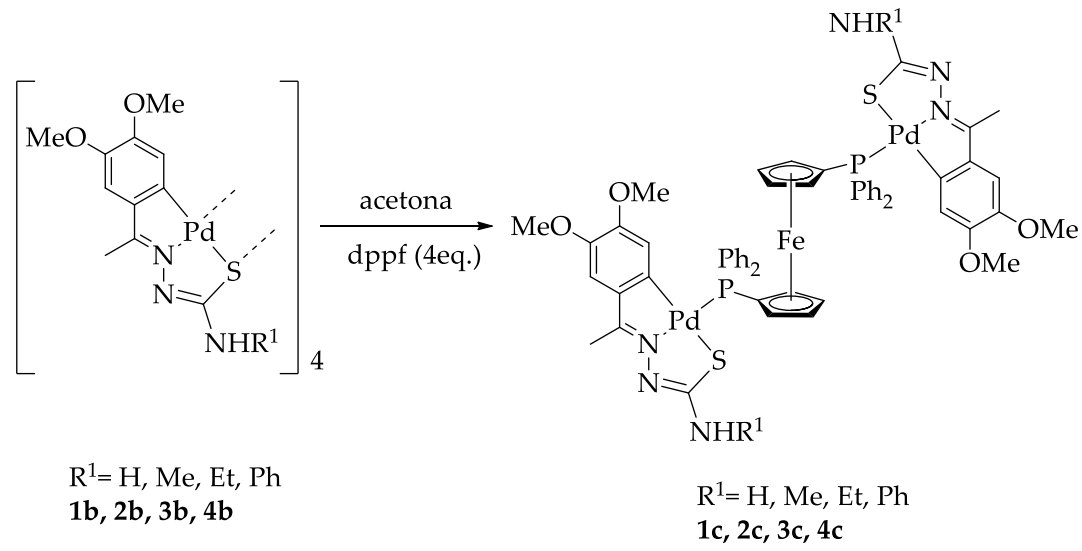

Scheme 3. Synthesis of the compounds bearing phosphine.

\section{Results and Discussion}

Analysis of the ${ }^{1} \mathrm{H}-\mathrm{NMR}$ data confirmed the formation of the ligand mainly due to the chemical shift of the signal of the hydrazinic proton (NNH). Cyclometallation was confirmed due to the differences of the signals in the aromatic zone with respect to those of the free ligand, namely the absence of the proton of the metallated carbon and also the signal for the hydrazinic proton disappears.

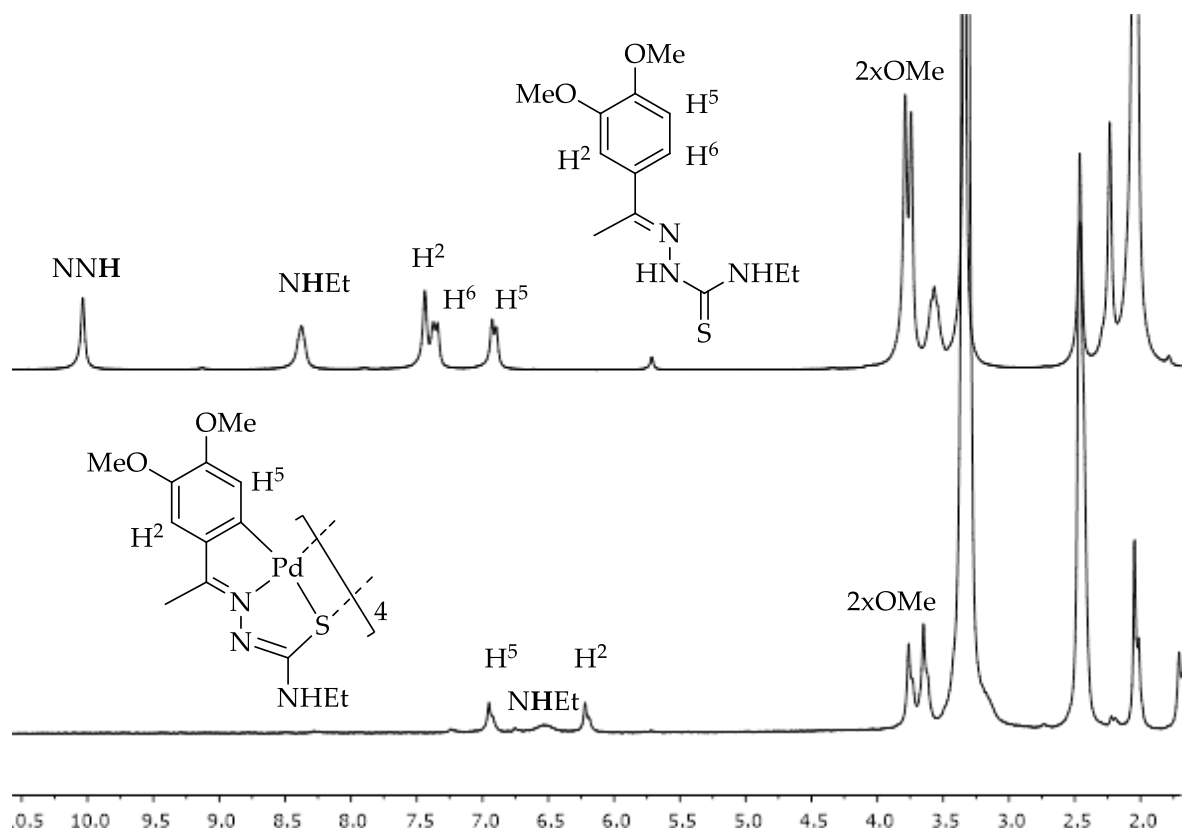

Figure 2. ${ }^{1} \mathrm{H}-\mathrm{NMR}$ spectra of $\mathbf{3} \mathbf{a}$ and $\mathbf{3} \mathbf{b}$ in DMSO-d6. 
In the IR spectra of the ligands, signals corresponding to $v(\mathrm{~N}-\mathrm{H})$ from the $\mathrm{NNH}$ and $\mathrm{NHR}^{1}$ groups were observed, whereas in the cyclometallated compounds the number of signals decreases due to the disappearance of the hydrazinic hydrogen.

Table 1. Infrared data in $\mathrm{cm}^{-1}$

\begin{tabular}{cccc}
\hline Ligand & $v(\mathrm{~N}-\mathrm{H})$ & Cyclometallated & $v(\mathrm{~N}-\mathrm{H})$ \\
\hline 1a & $3159 / 3269 / 3379$ & $\mathbf{1 b}$ & $3344 / 3452$ \\
2a & $3244 / 3328$ & $\mathbf{2 b}$ & 3376 \\
3a & $3240 / 3324$ & $\mathbf{3 b}$ & 3414 \\
$\mathbf{4 a}$ & $3254 / 3388$ & $\mathbf{4 b}$ & 3406 \\
\hline
\end{tabular}

The analysis of the ${ }^{1} \mathrm{H}-\mathrm{NMR}$ data confirmed the coordination of the phosphorus atoms to the metal center. There was a large upfield displacement of the signal corresponding to the $\mathrm{H}^{5}$ proton and coupling between $\mathrm{H}^{5}$ and the phosphorus nucleus. On the other hand the ${ }^{31} \mathrm{P}-\mathrm{NMR}$ showed the behavior of this phosphine as bidentate bridging because it showed a singlet signal $(c a++28 \mathrm{ppm})$ which indicates that both phosphorus nuclei are equivalent.

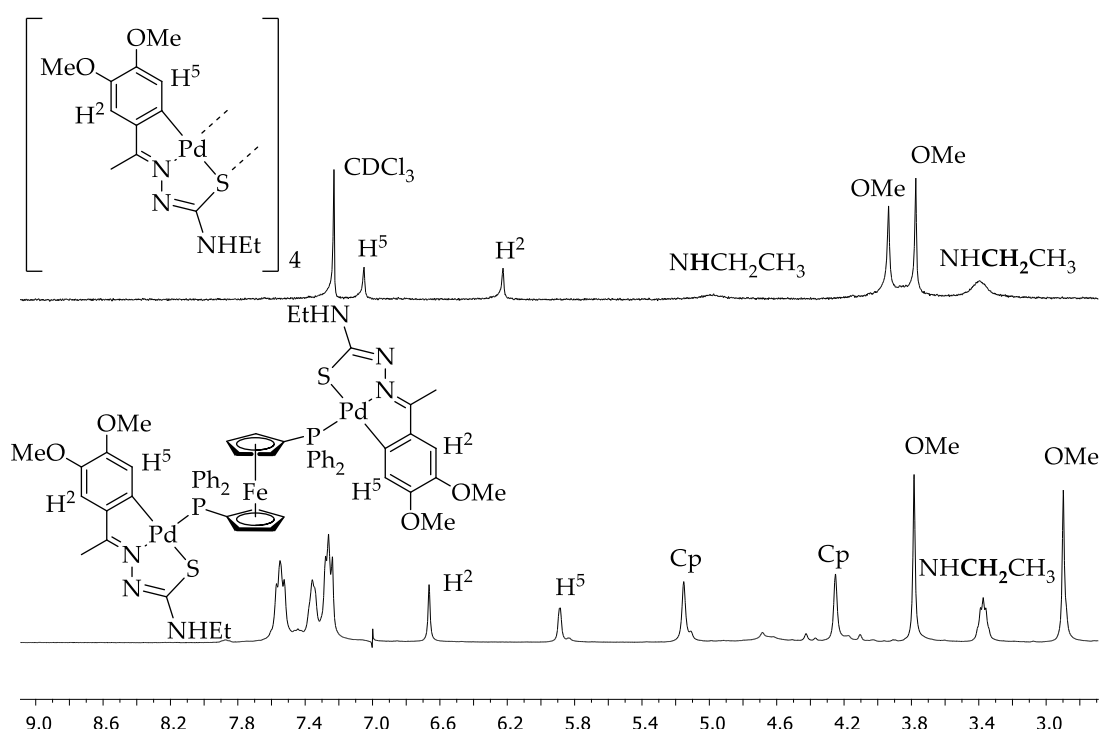

Figure 3. ${ }^{1} \mathrm{H}-\mathrm{NMR}$ spectra of $3 \mathbf{b}$ and $3 \mathbf{c}$ in $\mathrm{CDCl}_{3}$.

It has been possible to obtain crystals suitable for the X-ray diffraction of one of the cyclometallated compounds bearing diphosphine dppf (2c). The structure of the ligand is almost planar and the ferrocene maintains the alternated sandwich structure.
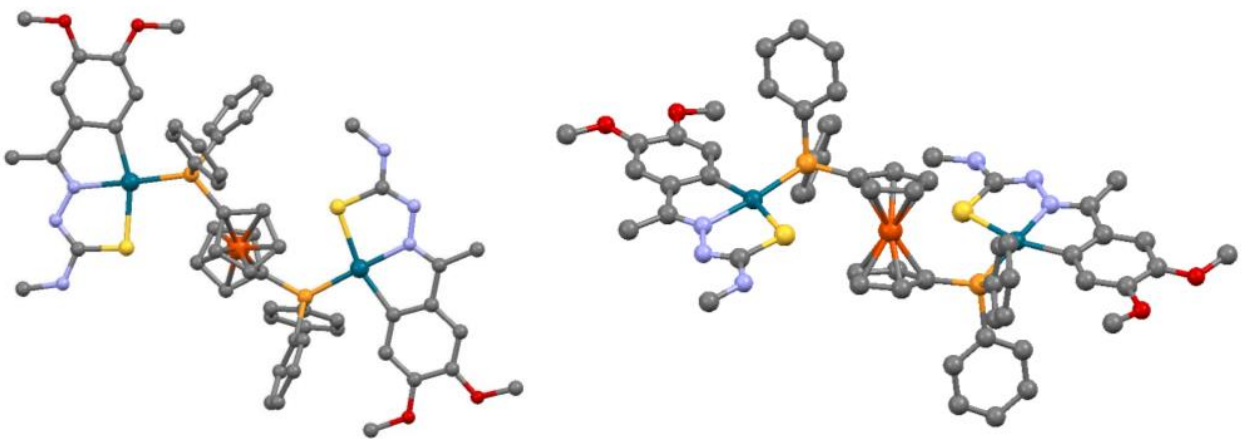

Figure 4. Two different views of the crystal structure of $2 c$. 
Table 2. Crystallographic data of 2c.

\begin{tabular}{ll}
\hline Empirical formula & C61 H64 Fe N6 O5 P2 Pd2 S2 \\
\hline Formula weight & 1355.89 \\
Temperature & $293(2) \mathrm{K}$ \\
Wavelength & $0.71073 \AA$ \\
Crystal system & Triclinic \\
Space group & $\mathrm{P}-1$ \\
Unit cell dimensions & $\mathrm{a}=11.148(5) \AA \AA \mathrm{a}=86.251(5)^{\circ}$ \\
& $\mathrm{b}=12.652(5) \AA ; \mathrm{b}=84.791(5)^{\circ}$ \\
& $\mathrm{c}=20.736(5) \AA ; \mathrm{g}=78.360(5)^{\circ}$ \\
Volume & $2849.4(18) \AA 3$ \\
Z & 2 \\
Density (calculated) & $1.580 \mathrm{Mg} / \mathrm{m} 3$ \\
Absorption coefficient & $1.061 \mathrm{~mm}-1$ \\
F(000) & 1384 \\
Crystal size & $0.22 \times 0.15 \times 0.04 \mathrm{~mm} 3$ \\
Theta range for data collection & 0.987 to $26.373^{\circ}$ \\
Index ranges & $-13<=\mathrm{h}<=13,-15<=\mathrm{k}<=15,-25<=1<=25$ \\
Reflections collected & 87669 \\
Independent reflections & $11617[\mathrm{R}(\mathrm{int})=0.0444]$ \\
Data / restraints / parameters & $11617 / 0 / 888$ \\
Goodness-of-fit on F2 & 1.028 \\
Final R indices [I $>2$ sigma(I)] & $\mathrm{R} 1=0.0273, \mathrm{wR} 2=0.0588$ \\
R indices (all data) & $\mathrm{R} 1=0.0405, \mathrm{wR} 2=0.0632$ \\
Largest diff. peak and hole & 0.675 and $-0.662 \mathrm{e} . \AA-3$ \\
\hline
\end{tabular}

Acknowledgments: We wish to thank the financial support received from the Xunta de Galicia (Galicia, Spain) under the Grupos de Referencia Competitiva Programme Projects GRC2015/009.

Conflicts of Interest: "The authors declare no conflict of interest". "The founding sponsors had no role in the design of the study; in the collection, analyses, or interpretation of data; in the writing of the manuscript, and in the decision to publish the results".

\section{References}

1. Prabhu, R. N.; Ramesh, R. Synthesis and structural characterization of palladium(II) thiosemicarbazone complex: application to the Buchwald-Hartwig amination reaction. Tetrahedron Lett. 2013, 54, 1120-1124, https://doi.org/10.1016/j.tetlet.2012.12.070.

2. Prabhu, R. N.; Ramesh, R. Catalytic application of dinuclear palladium(II) bis(thiosemicarbazone) complex in the Mizoroki-Heck. Reaction. Tetrahedron Lett. 2012, 53, 5961-5965, 10.1016/j.tetlet.2012.08.120.

3. Cruz, S.; Bernès, S.; Sharma, P.; Vazquez, R.; Hernández, G.; Portillo, R.; Gutiérrez, R. Synthesis, characterization and anticancer activity of new palladacycles derived from chiral $\alpha$-diimines. Appl. Organomet. Chem. 2010, 24, 8-11, 10.1002/aoc.1570.

4. Togni, A. and Hayashi, T. (eds) (1994) Ferrocenes, Wiley-VCH Verlag GmbH, Weinheim, Germany. 10.1002/9783527615599. 
5. Kalaivani, P.; Prabhakaran, R.; Dallemer, F.; Poornima, P.; Vaishnavi, E.; Ramachandran, E.; Padma, V. V.; Renganathan, R.; Natarajan, K. DNA, protein binding, cytotoxicity, cellular uptake and antibacterial activities of new palladium(II) complexes of thiosemicarbazone ligands: effects of substitution on biological activity. Metallomics : integrated biometal science 2012, 4, 101-113, 10.1039/c1mt00144b.

6. Budzisz, E.; Bobka, R.; Hauss, A.; Roedel, J. N.; Wirth, S.; Lorenz, I. P.; Rozalska, B.; Wieckowska-Szakiel, M.; Krajewska, U.; Rozalski, M. Synthesis, structural characterization, antimicrobial and cytotoxic effects of aziridine, 2-aminoethylaziridine and azirine complexes of copper(ii) and palladium(ii). Dalton Trans. 2012, 41, 5925-5933, 10.1039/C2DT12107G.

7. Kostas, I. D.; Andreadaki, F. J.; Kovala-Demertzi, D.; Christos, P.; Demertzis, M. A. Suzuki-Miyaura cross-coupling reaction of aryl bromides and chlorides with phenylboronic acid under aerobic conditions catalyzed by palladium complexes with thiosemicarbazone ligands. Tetrahedron Lett. 2005, 46, 1967-1970, 10.1016/j.tetlet.2005.02.003.

8. Kovala-Demertzi, D.; Kourkoumelis, N.; Derlat, K.; Michalak, J.; Andreadaki, F. J.; Kostas, I. D. Thiosemicarbazone-derivatised palladium nanoparticles as efficient catalyst for the Suzuki-Miyaura cross-coupling of aryl bromides with phenylboronic acid. Inorg. Chim. Acta 2008, 361, 1562-1565, 10.1016/j.ica.2007.09.038.

9. Antelo, J. M.; Adrio, L.; Bermúdez, B.; Martínez, J.; Teresa Pereira, M.; Ortigueira, J. M.; López-Torres, M.; Vila, J. M. Spectroscopic and solid state characterization of bimetallic terdentate [C,N,S] thiosemicarbazone Palladium(II) metallacycles with bridging and chelating [P,P] diphosphine ligands. J. Organomet. Chem. 2013, 740, 83-91, 10.1016/j.jorganchem.2013.04.036.

10. Li, G.; Wang, J.; Yuan, B.; Zhang, D.; Lin, Z.; Li, P.; Huang, H. Iron-catalyzed one-pot synthesis of benzimidazoles from 2-nitroanilines and benzylic alcohols. Tetrahedron Lett. 2013, 54, 6934-6936, 10.1016/j.tetlet.2013.10.045.

11. Kawatsura, M.; Hirakawa, T.; Tanaka, T.; Ikeda, D.; Hayase, S.; Itoh, T. Regioselective synthesis of trifluoromethyl group substituted allylic amines via palladium-catalyzed allylic amination. Tetrahedron Lett. 2008, 49, 2450-2453, 10.1016/j.tetlet.2008.02.034.

12. Yokogi, M.; Kuwano, R. Use of acetate as a leaving group in palladium-catalyzed nucleophilic substitution of benzylic esters. Tetrahedron Lett. 2007, 48, 6109-6112, 10.1016/j.tetlet.2007.06.157.

13. Hao, X.-Q.; Gong, J.-F.; Du, C.-X.; Wu, L.-Y.; Wu, Y.-J.; Song, M.-P. Synthesis, characterization and photoluminescent properties of platinum complexes with novel bis(imidazoline) pincer ligands. Tetrahedron Lett. 2006, 47, 5033-5036, 10.1016/j.tetlet.2006.05.096.

(C) 2017 by the authors. Submitted for possible open access publication under the (C) (9) terms and conditions of the Creative Commons Attribution (CC BY) license (http://creativecommons.org/licenses/by/4.0/). 